\title{
Parametric Simulation and Exergy Analysis of a 30w Ethanol Fuel Cell: A Theoretical Approach
}

\author{
Emeniru Daniel C, \\ Chemical Engineering, Federal Polytechnic Oil and Gas Ekowe, \\ Bayelsa State, Nigeria \\ Chemical Engineering, Ahmadu Bello University, Zaria, Nigeria \\ Ogoro Zino Bright, \\ Osazee Ogbeifun E., \\ Owutuamor Fredrick T.,
}

Electrical/Electronic Engineering, Federal Polytechnic Oil and Gas Ekowe, Bayelsa, Nigeria

Olawale Adegboyega S.,

Oguche John Enemona,

Chemical Engineering, Ahmadu Bello University, Zaria, Nigeria

Doi:10.19044/esj.2022.v18n3p121

Submitted: 02 October 2021

Accepted: 17 December 2021

Published: 31 January 2022
Copyright 2022 Author(s)

Under Creative Commons BY-NC-ND 4.0 OPEN ACCESS

Cite As:

Emeniru D.C., Bright O.Z., Osazee O.E., Owutuamor F.T., Olawale A.S.,Oguche J.E., (2022). Parametric Simulation and Exergy Analysis of a 30w Ethanol Fuel Cell: A Theoretical Approach European Scientific Journal, ESJ, 18 (3), 121.

https://doi.org/10.19044/esj.2022.v18n03p121

\section{Abstract}

Ethanol has the potential of being an abundant biofuel considering the raw materials and indigenous technology available. Due to its oxidation tendency, higher energy density, nontoxic and environmental affability, several studies have confirmed and emphasized ethanol's choice and adaptability for usage in fuel cells. This paper aimed at parametric simulation and exergy analysis of a 30W ethanol fuel cell using a theoretical approach. The simulation considers $1 \mathrm{~atm}$ and $65^{\circ} \mathrm{C}$ operating conditions while making empirically significant assumptions about layer thicknesses and other parameters. Fixed and standard parameters from the literature were applied in the mathematical expressions and models that described the energy, power generation, over-potentials, and the efficiencies inherent in the simulation. From the simulation, voltage loss due to transport contributed about $80 \%$ of 
the $0.1211 \mathrm{~V}$ while total over-potential culminated to the 3.633W irreversible power. The exergy analysis of the simulated 95\% Direct Ethanol Fuel Cell (DEFC) gave 89\% cell efficiency for the generation of 3,050 kJ energy, 33.80 $\mathrm{W}$ ideal power, and $30.28 \mathrm{~W}$ useful power in a 90 seconds operation at a $1.1267 \mathrm{~V}$ potential.

Keywords: Fuel cells, Ethanol, Simulation, Voltage loss, Efficiency, Exergy

\section{INTRODUCTION}

In the bid to rein the greenhouse effect through clean energy, advancement in fuel cell simulation and design has taken the topnotch position in virtually all portable devices and is tending to be another key source of energy alongside the solar power source that is mainly for domestic use. This advancement has remained constant in the quest to develop fuel cells (FC) that will meet economic and environmental quantity and standards.

A fuel cell is an electrochemical device that converts chemical energy directly into electrical energy with high efficiency. Not only on efficient energy generation; about $45 \%$ reduction in greenhouse gas emission has been ensured with the use of ethanol (Renewable Fuels Association (RFA), 2021). The ethanol fuel cell has advantages over other fuel cells considering the availability of ethanol directly and the ease in its numerous means of production from agricultural waste. It has high-energy conversion: about $80 \%$ and has widespread applications due to its potentials for power generation (Abdulrazzak \& Abdullah, 2021). The major drawback of microbial fuel cells that gave the leap for the ethanol fuel cell is the huge amount of catalysts required. These catalysts are not easily synthesized due to high time and resource demand. Hence, they are not readily available commercially or preparatorily (Santoro et al., 2018). Considering the size of the electrical cells, fuel of high economic viability is very important in coupling a highperformance FC. Fuel cells are applicable as sources of primary and backup power in buildings, vehicles, small electrical appliances, electronic gadgets, etc., and are capable of producing more than $250 \mathrm{~W}$ power. According to the report of Abdullah et al. (2014), the FC energy density for such devices is increasing 3 to 10 times faster than the lithium battery energy density currently in use. When power is the target, energy and power densities at optimum conditions become more important features than efficiency.The world is experiencing global warming, which is mostly caused by the incomplete combustion of fossil fuels and the subsequent emission of damaging nonbiodegradable gases (Modupe, et al., 2018). Nigeria is known to be one of the world's major petroleum-producing countries (Oyegoke \& Dabai, Technoeconomic feasibility study of bioethanol production from a combined 
cellulose and sugar feedstock in Nigeria: 1-modeling, simulation, and cost evaluation., 2018). However, petroleum as a fossil fuel, as well as other chemicals are important sources of power in cells, the use of bio-fuel is preferred due to the leverage on health and environmental friendliness. Studies have not denied the preference of hydrogen to other fuels as the most benign. However, generating hydrogen requires a very complex and costly system. However, methanol remains the fuel with very high electrochemical activity till date, its lethargic anode kinetics and high fuel crossover (Elleuch, Halouani, \& Li, 2016) begot its relegation in fuel cell applications. Hence, research reportage on the continuing quest for a better alternative has brought ethanol to the fore in recent applications and studies. Ethanol, as bio-fuel, is an alternative to fossil fuel having high octane number, high heating value and undergoes complete combustion in automobiles due to its high oxygen content, which leads to fewer emissions of poisonous gases (Ajayi, Rasheed, Abiodun, \& Toyese, 2020). As alcohol, it has comparable energy density to that of fossil fuels - gasoline and diesel (Braide, Kanu, Oranusi, \& Adeleye, 2016). It is preferred for its oxidation tendency, higher energy density, nontoxicity, lower crossover rate and environmental friendliness (Zakaria, Kamarudin, \& Timmiati, 2016). It is also readily and naturally available as well as abundant.While Nigeria was aiming at 1.27 billion liters (335 million gallons) of ethanol for the year 2011 (Agboola \& Agboola, 2011), the world production stood at 22.5 billion gallons (Renewable Fuel Association, 2018). The Nigerian urban and rural areas are typical of heavy biomasses, waste constituents, and plant parts and products inherent for ethanol production. Traditionally, in energy generation, biomass and waste constitute $74 \%$ while oil, natural gas and hydropower consist of $13 \%, 12 \%$ and $1 \%$, respectively (Oyegoke, Dabai, Muhammed, \& Jibril, 2017).Ethanol is a biofuel chiefly gotten via the biochemical process of fermentation and biodegradation of agro-allied products: palm-wine, food crops, plant parts, biomasses, and even municipal waste. The advent of ethanol heralds an era of renewable and clean energy fuel with relative equivalent performance and efficiency (Saisirirat \& Joommanee, 2018) with other energy sources hence the arrival of the Direct Ethanol Fuel Cell (DEFC).There is yet no fuel cell that has met the optimum parameter (conditions and materials) for an ideal fuel cell in terms of operating temperature and pressure, electrolyte and membrane type, cell structure, the exchangeable ions, and the reactants in the electrolyte; hence fuel cells are classified based on these parameters. Every operating condition and material consideration for a fuel cell has its demerits, thus, substantial considerations in simulations, models, and designs are based on availability and convenience. To conserve, hence reduce losses, simulations for power generation need a lot of loss control and performance improvement. Therefore, the use of thin 
materials implies a lighter product with reduced losses due to resistivity and improved conductivity for performance enhancement.

Low ethanol permeability and high conductivity are primary features of a suitable electrolyte membrane for DEFCs. Amidst SiC ceramic membrane (Back-Sub \& Young-Hoon, 2016); and polybenzimidazole (PBI), polyvinyl alcohol (PVA), and sulfonated poly-ether ether ketone (SPEEK) (Zakaria, Kamarudin, \& Timmiati, 2016). Research has reported anion exchange membrane (AEM) as more suitable in DEFC design and setup (Back-Sub \& Young-Hoon, 2016). The preference of electrocatalyst is measured by the lowest possible onset potential: DHE - dynamic hydrogen reference electrode (Abdullah, Kamarudin, Hasran, \& Daud, 2014). Song \& Tsiakaras (2006) reported DHE 85 for PtSn/C at the same condition where PtRu/C and Pt gave 200 and 380, respectively.

In every FC design as in DEFC, voltage losses have remained a limitation. Voltage losses, polarization or over potential include activation loss due to charge transfer reactions at electrodes, loss due to fuel crossover from anode to cathode, Ohmic loss due to materials' conductivity, concentration loss due to transfer resistance, and reactant availability at reaction sites, and other traces of losses. Fuel cross over to the cathode reduces the amount of ethanol available for power generation. Energy leakage due to poor material contact and the energy loss due to heat in materials of poor conductivity reduce the quantity of useful energy. Transfer resistances due to pore blockage and flooding limit the amount of the reactant $\left(\mathrm{EtOH} / \mathrm{O}_{2}\right)$ needed at the reaction sites to generate the expected energy.

However, in the simulation model, these losses can be managed depending on the amount of expected power, materials (electrode, diffusion layer and, catalyst, and electrolyte membrane) used, as well as the cell operating condition. These losses define the system's irreversibility. It is noteworthy that FC models, simulations, designs and the consequent manufacture is tailored towards electrical power generation for electrical appliances. The performance of any FC is mirrored by the simulated efficiencies. The efficiencies that can be simulated in a FC model and design encompass the thermodynamic efficiency (reversible efficiency, $\varepsilon_{t h}$ ), the ideal electrochemical efficiency $\left(\varepsilon_{\text {elect }}\right)$, and the cell efficiency $\left(\varepsilon_{c e l l}\right)$ among other efficiencies and performance measures as shown in Figure 1 
These extensive theoretical and empirical studies on DEFC are geared towards hastening and strengthening its application in portable electronic devices. Amidst other shared merits of the DEFC, it is typical of fuel replacement, rapid starting, low operating temperature and comparative high current density. Chiefly, the literature has reported virtually on the mathematical modeling, and the current and potential of DEFC. In the recent past, few works have considered simulation and exergy analysis in fuel cells.

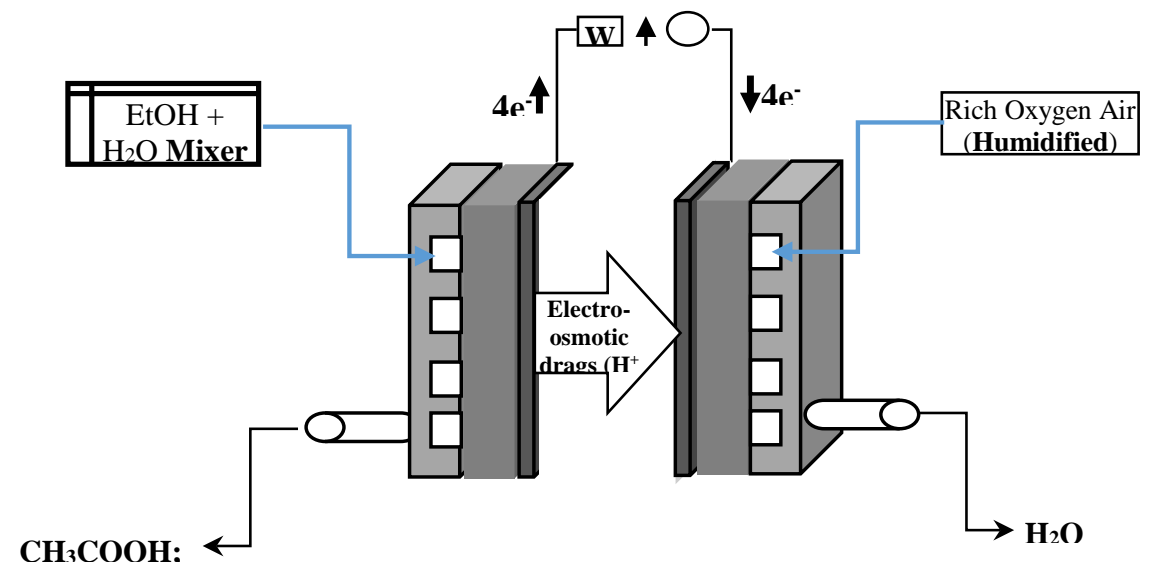

Fig 1: Schematic Diagram for the Ethanol Bio-Fuel Cell

Studying the possible configuration of hybrid power plants, Abdulrazzak and Abdullah, (2021) considered theoretical simulation and exergy analysis. In a bid to improve reactant usage for higher efficiency, Mert, Toprak, and Depci, (2019) looked at the simulation and exergy of several proton exchange membrane (PEM) FC flow channels. Temperature enhancement of FC performance has gotten wide reportage over a decade now. The simulation and exergy of high-temperature membrane fuel cell has been studied in (Haghighi \& Sharifhassan, 2016), even though this work did not give empirical concern to the fuel and its chemistry. Works on the exergy analysis of alcohol fuel cell have been very scanty with much interest given to Methanol amidst the few studies reported. The literature has no report or study on the simulation and exergy of a DEFC for a specific power generation. This work, therefore, considered the empirical chemistry of ethanol as a direct fuel for a parametric simulation and exergy analysis of a 30W fuel cell. The simulation would expose parameters, besides standard values, that can sway the power generation and the over-potential with respect to the available materials and the target power output. 


\section{Simulation}

\section{The Simulation Considerations}

Low feed concentration has been reported as a key parameter to mitigate ethanol crossover via reducing the electro-osmotic drag of ethanol and as well limiting the current density, and vice versa (Zakaria, Kamarudin, \& Timmiati, 2016), hence $0.003-0.005 \mathrm{~mol} / \mathrm{cm}^{3}$ and $0.03-0.05 \mathrm{~g} / \mathrm{s}$ were supposed optimum in this simulation. This simulation considered a $95 \%$ ethanol of density $0.789 \mathrm{~g} / \mathrm{cm}^{3}$ and molar mass $46.07 \mathrm{~g} / \mathrm{mol}$. A $20 \%$ ethanol aqueous solution formed from $19 \mathrm{ml} 95 \% \mathrm{EtOH}$ and $76 \mathrm{ml}$ distilled water. A $2 \mathrm{~cm}^{3} / \mathrm{s}$ EtOH feed rate was used.

The actual efficiency and performance of DEFC is low attributive to the incomplete oxidation to $\mathrm{CO}_{2}$ resulting from slow electro-oxidation (EOR) due to a low operating temperature (Song \& Tsiakaras, 2006; Abdullah, Kamarudin, Hasran, \& Daud, 2014). To attain a near empirical simulation, a steady-state complete conversion of ethanol to acetaldehyde $\left(\mathrm{CH}_{3} \mathrm{CHO}\right)$ then to acetic acid $\left(\mathrm{CH}_{3} \mathrm{COOH}\right)$ and $\mathrm{CO}_{2}$ was assumed.

Ideally, the elementary equations for the complete ethanol oxidation is given as:

Anode:

$$
\mathrm{C}_{2} \mathrm{H}_{5} \mathrm{OH}+3 \mathrm{H}_{2} \mathrm{O} \rightarrow 2 \mathrm{CO}_{2}+12 \mathrm{H}^{+}+12 \mathrm{e}^{-}
$$

Cathode:

$$
3 \mathrm{O}_{2}+12 \mathrm{H}^{+}+12 \mathrm{e}^{-1} \rightarrow 6 \mathrm{H}_{2} \mathrm{O}
$$

Overall:

$$
\mathrm{C}_{2} \mathrm{H}_{5} \mathrm{OH}+3 \mathrm{O}_{2} \rightarrow 2 \mathrm{CO}_{2}+3 \mathrm{H}_{2} \mathrm{O}
$$

Therefore, the incomplete oxidation typical of acetic acid formation was considered as:

Anode:

$\mathrm{C}_{2} \mathrm{H}_{5} \mathrm{OH}+2 \mathrm{H}_{2} \mathrm{O} \rightarrow \mathrm{CH}_{3} \mathrm{COOH}+\mathrm{H}_{3} \mathrm{O}^{+}+3 \mathrm{H}^{+}+4 \mathrm{e}^{-}$

(4)

Cathode:

$$
\mathrm{O}_{2}+\mathrm{H}_{3} \mathrm{O}^{+}+3 \mathrm{H}^{+}+4 \mathrm{e}^{-1} \rightarrow 3 \mathrm{H}_{2} \mathrm{O}
$$

Overall:

$$
\mathrm{C}_{2} \mathrm{H}_{5} \mathrm{OH}+\mathrm{O}_{2} \rightarrow \mathrm{CH}_{3} \mathrm{COOH}+\mathrm{H}_{2} \mathrm{O}
$$

(6) 


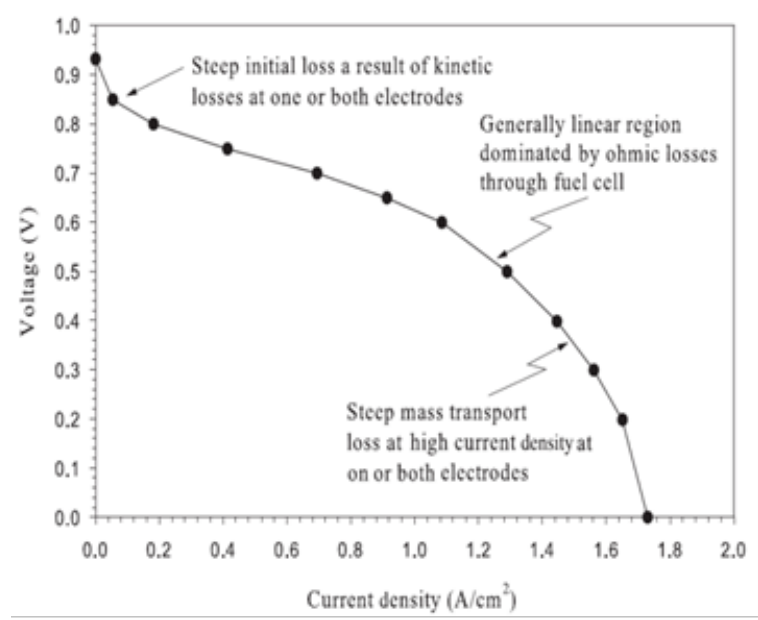

Fig 2: The Polarization Curve

Considering that elementary reaction order cannot be fractional, anodic oxidation order of 1.0 and the ORR order of 0.75 were used. Voltages between 0.5 and $0.6 \mathrm{~V}$ at normal operating loads are typical for a real fuel cell and can reach $1.1 \mathrm{~V}$ at open-circuit conditions. It follows that electrochemical efficiency can typically be approximated between 40 and 50\% for open circuit conditions and reaching 90\% (Mench, 2008). All current densities considered for the over-potentials were obtained from the polarization curve (Fig. 2). The linear region of the curve showed current density ranging $1.1-1.3 \mathrm{~A} / \mathrm{cm}^{2}$ typical for ohmic losses, $i=0.06 \mathrm{~A} / \mathrm{cm}^{2}$ current density was obtained from the activation region. Anodic and cathodic charge transfer coefficients adopted were 0.089 and 1.00 respectively (Saisirirat \& Joommanee, 2018; Andreadis, Podias, \& Tsiakaras, 2008).

Nafion 112: $51 \mu \mathrm{m}$ and $\approx 60 \mu \mathrm{m}$ thick in a wet state (Mench, 2008), graphite plate (GP) were chosen as the cell membrane and the current collector respectively. Anode and cathode diffusion and catalyst layer was assumed to be of equal dimension and that electro oxidation occurs in the middle of the CL. A $250 \mu \mathrm{m}$ DL thickness of $20 \%$ polytetraflouroethelyne (PTFE) and $2 \times 10^{4}$ $\mathrm{S} / \mathrm{m}$ conductance was considered. A $30 \mathrm{~m} \Omega . \mathrm{cm}^{2}$ contact resistance for a Landing to channel ratio of 3:1 was adopted. Due to the low operating temperature and rapid diffusion, anodic polarization was assumed negligible.

At the cell operating condition, the humidified air is generated at $80^{\circ} \mathrm{C}$, $1 \mathrm{~atm}$ and would enter the cell at $65^{\circ} \mathrm{C}, 1 \mathrm{~atm}$. Characteristic values of $\boldsymbol{m}$ and $\boldsymbol{n}$ from several fitted polarization curves for a Polymer Electrode Fuel Cell (PEFC) fall around $3 \times 10^{-5} \mathrm{~V}$ and $8.00 \mathrm{~cm}^{2} / \mathrm{A}$ respectively (Mench, 2008). The current density that compels reactant mass transport at the electrodes for a typical operating condition of a PEFC ranges $1.0-1.55 \mathrm{~A} / \mathrm{cm}^{2}$ for mild to steep loss (Ehlinger, Andrew, Ahmet, \& Adam, 2020; Mench, 2008). 


\section{The Simulation Assumptions}

At the cathode, considering voltage loss due to oxygen concentration, exchange current density (i) was constant and transfer resistance for the oxygen reduction reaction negligible. The relative humidity of unity was considered for the humidified air carrying and charging the oxygen. All likely chemical energies in the reaction went into electrical work, hence there was no heat transfer and no entropy change.

Over-potential due to electrical short circuits, mixed- potential due to EtOH crossover, ionic and electronic transfer, etc. can be managed via design consideration and material selection, hence were regarded negligible.

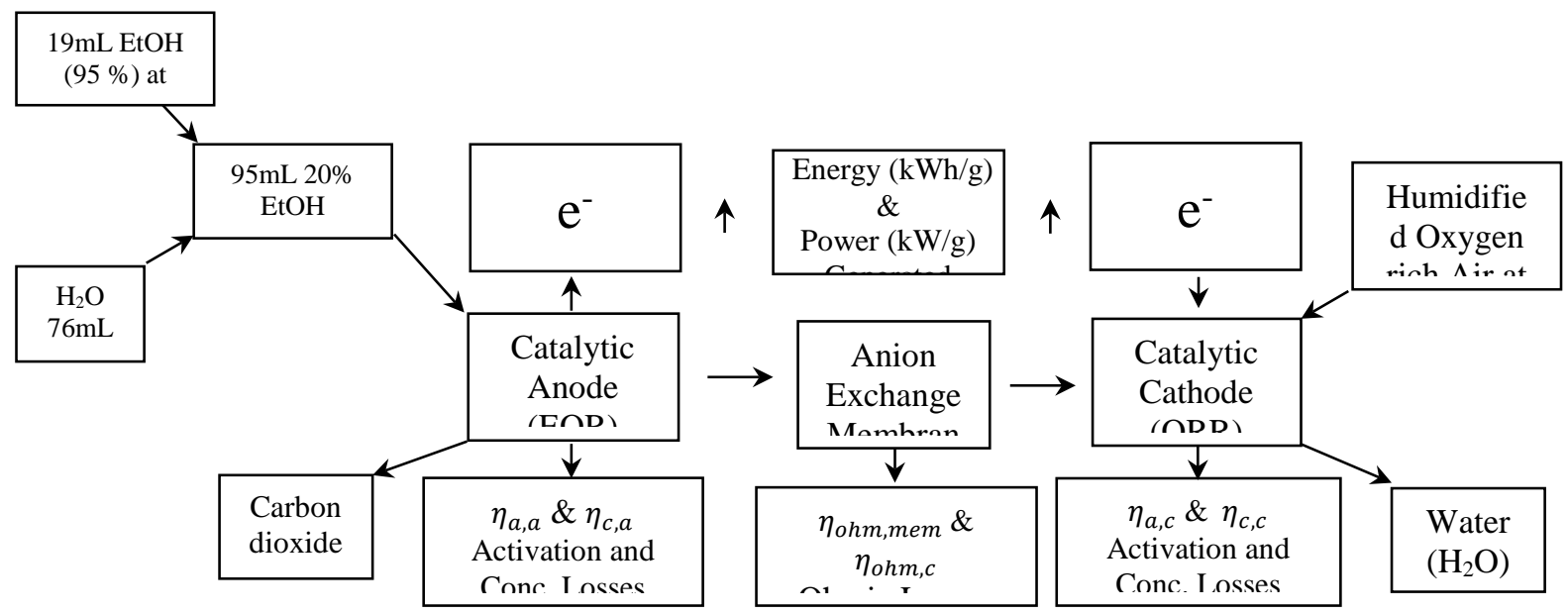

Fin 3: Process Flow Diagram for the Ethanol Bio-Fuel Cell

\section{The Simulation Calculations}

A $0.01627 \mathrm{~mol} / \mathrm{cm}^{3}$ reference concentration was calculated for the $95 \%$ ethanol stock and a $0.0034 \mathrm{~mol} / \mathrm{cm}^{3}$ feed concentration was considered from the $20 \%$ ethanol feed. The process flow diagram showed a $95 \mathrm{~mL}$ reservoir of $20 \%$ ethanol charged at the Cell operating temperature $\left(65^{\circ} \mathrm{C}\right)$ and $2 \mathrm{~cm}^{3} / \mathrm{s}$; therefore, $0.0068 \mathrm{~mol} / \mathrm{s}$ of ethanol was charged into the cell channels.

The cell stoichiometry showed the release of $4 \mathrm{e}^{-}$from the oxidation of 1 mole EtOH, giving a $0.0272 \mathrm{e}^{-}$release for 0.0068 moles fed. The cell open circuit current from Faradays second law relation for a $0.0068 \mathrm{~mol} / \mathrm{s}$ feed and 0.0272 electron charge released was calculated as $17.846 \mathrm{~A}$; taking $\mathrm{F}=$ 96485C:

$$
I_{o}=i_{o} \mathrm{~A}=N n F=0.0068 \times 0.0272 \times 96485=17.846 \mathrm{~A}
$$

Current and power losses in FCs depends on the application of resistivity concept. Practicably, the thinnest materials are considered. Thus, a cell of $0.41 \mathrm{~cm}$ componential thickness, $10 \mathrm{~cm}$ height and $5 \mathrm{~cm}$ width will give $50 \mathrm{~cm}^{2}$ 
2D contact surface available for current flow. Therefore, the anodic reference exchange current was $0.3569 \mathrm{Acm}^{2}$ :

$$
i_{o, \text { ref }}=17.846 \mathrm{~A} / 50 \mathrm{~cm}^{2}=0.3569 \mathrm{~A} \cdot \mathrm{cm}^{-2}
$$

With $C_{\text {ref }, E t O H}=0.01629 \mathrm{~mol} / \mathrm{cm}^{3}$ and $C_{F, E t O H}=0.0034 \mathrm{~mol} / \mathrm{cm}^{3}$; considering the elementary reaction order 1.0 , the exchange current density: $0.0744 \mathrm{Acm}^{2}$ was calculated;

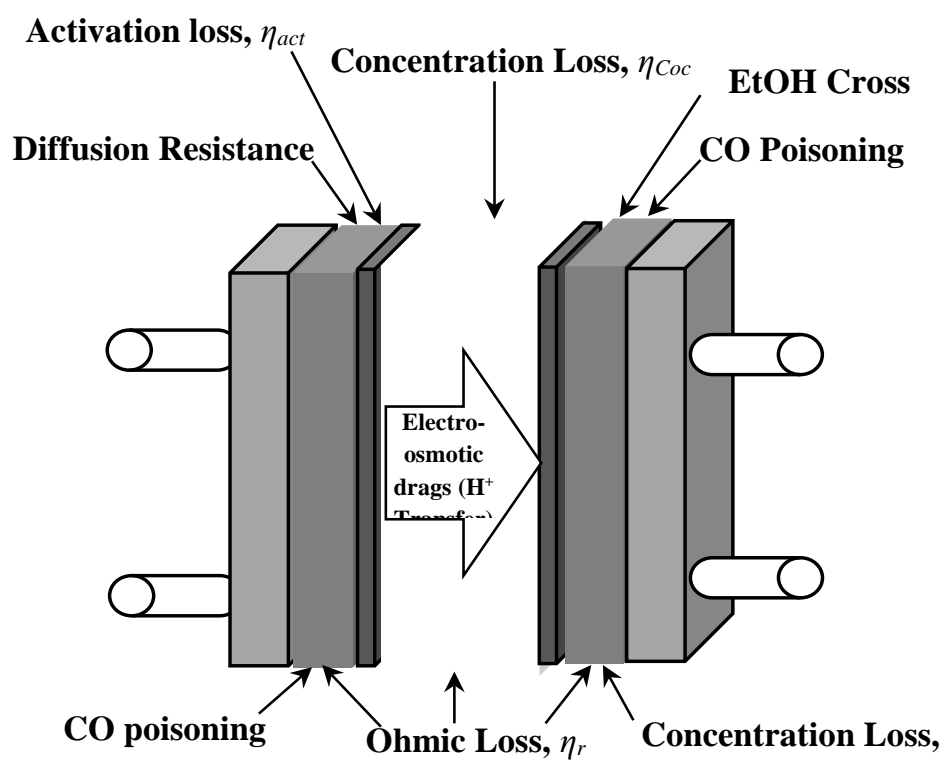

Fig 4: DEFC Schematic showing Points of Losses

Activation Loss: Predicting low polarization, the Butler-Volmer (BV) facile kinetic model was applied:

$$
\eta_{\mathrm{a}}=\frac{i}{i_{o}} \frac{\mathrm{RT}}{\left(\alpha_{a}+\alpha_{c}\right) \mathrm{F}}=\frac{i}{i_{o}} \frac{\mathrm{RT}}{n \mathrm{~F}}
$$

Taking $i=0.06 \mathrm{~A} / \mathrm{cm}^{2}$ and 0.089 and 1.00 anodic and cathodic charge transfer coefficients respectively, $0.0216 \mathrm{~V}$ was lost due to activation:

$\eta_{\mathrm{a}}=\frac{i}{i_{o}} \frac{\mathrm{RT}}{n \mathrm{~F}}=\frac{0.06 \times 8.314 \times 338}{0.0744 \times 1.089 \times 96485}=0.0216$

Ohmic (Conduction) Loss is chiefly due to Current flow, hence is based on the concept and law of resistivity. Reducing Ohmic losses entails applying the thinnest and highest possible conductivity material components (electrolyte, catalyst and diffusion materials) in the cell design and manufacture.

Ohms Law:

$$
\mathrm{V}=\mathrm{IR}=i A R=i \mathrm{~A}(l / \sigma A)
$$


Thus:

$$
\begin{gathered}
\eta_{\mathrm{r}}=i A \sum_{j=1}^{n} l_{\mathrm{j}} / \sigma_{\mathrm{j}} A=\eta_{\text {ionic }}+\eta_{\text {elect }}+\eta_{\text {contact }} \\
\eta_{\mathrm{r}}=i A\left\{\left(\frac{l_{a}}{{\mathrm{a}_{\mathrm{a}} \sigma_{a} A}_{1}}+\frac{l_{e}}{\sigma_{e} A}+\frac{l_{c}}{\mathrm{l}_{c} \sigma_{c} A}\right)+\left(\frac{l_{G P}}{\sigma_{G P} A}+\frac{l_{D L}}{\sigma_{D L} A}+\frac{l_{C L}}{2 \sigma_{C L} A}\right)+\frac{\mathrm{R}_{\mathrm{GBP}}}{\mathrm{A}_{\mathrm{L}}}+\frac{\mathrm{R}_{\mathrm{L}}}{\mathrm{A}_{\mathrm{L}}}\right\}
\end{gathered}
$$

Having a cell of $0.41 \mathrm{~cm}$ thickness and $10 \mathrm{~cm}$ height, $4.1 \mathrm{~cm}^{2}$ active area would be available for Ohmic loss. In a demonstrative estimation, Mench (2008) reported that thin electrolytes support high current densities. Therefore, for a $1.10 \mathrm{~A} / \mathrm{cm}^{2}$ when electro oxidation occurred at the middle of the CL, taking respectively $30 \%$ and $40 \%$ anode and cathode ionomer (i) equivalents, $9.70 \times 10^{-6} \mathrm{~V}$ was lost due to ion conductivity for a $59 \mu \mathrm{m}$ thick wet Nafion ${ }^{\circledR} 112$ (Mench, 2008):

\section{Ionic Loss:}

$\eta_{\text {ionic }}=i\left(\frac{l_{a}}{l_{\mathrm{a}} \sigma_{e}}+\frac{l_{e}}{\sigma_{e}}+\frac{l_{c}}{\mathrm{c}_{c} \sigma_{e}}\right)=1.10\left(\frac{2.5 \times 10^{-6}}{0.3 \times 5}+\frac{59 \times 10^{-6}}{10}+\frac{2.5 \times 10^{-6}}{0.4 \times 5}\right)=9.6984 \times 10^{-6} \mathrm{~V}$

The flexibility of the woven-carbon-cloth DL makes for its durability hence its preference to the bristle nonwoven-paper DL that can barely withstand mechanical strain (Mench, 2008). Hence $7.84 \times 10^{-7} \mathrm{~V}$ was lost due to electron mobility in the $0.025 \mathrm{~cm}$ thick DL of $20 \%$ polytetraflouroethelyne (PTFE) of $2 \times 10^{4} \mathrm{~S} / \mathrm{m}$ conductance:

\section{Electronic Loss:}

$$
\eta_{\text {elect }}=i\left(\frac{l_{G P}}{\sigma_{G P}}+\frac{l_{D L}}{\sigma_{D L}}+\frac{l_{C L}}{2 \sigma_{C L}}\right)=1.10\left(\frac{4 \times 10^{-3}}{2 \times 10^{4}}+\frac{25 \times 10^{-5}}{2 \times 10^{4}}+\frac{5 \times 10^{-6}}{2 \times 5}\right)=7.84 \times 10^{-7} \mathrm{~V}
$$

For a 3:1 Landing to Channel ratio: $A_{G P}=0.75 \mathrm{~A}=0.75 \times 4.1=3.075 \mathrm{~cm}^{2}$ and for the DL-CL contact surface area which is equal the 2D surface area of either the DL or the CL: $A_{\mathrm{L}}=5 \times 10=50 \mathrm{~cm}^{2}$ :

\section{Contact Loss:}

$$
\eta_{\text {contact }}=i A\left(\frac{\mathrm{R}_{\mathrm{GP}}}{\mathrm{A}_{\mathrm{GP}}}+\frac{\mathrm{R}_{\mathrm{L}}}{\mathrm{A}_{\mathrm{L}}}\right)=1.10 \times 4.1\left(\frac{30 \times 10^{-3}}{3.075}+\frac{30 \times 10^{-3}}{50}\right)=0.0467 \mathrm{~V}
$$

Therefore;

$$
\eta_{\mathrm{r}}=9.6984 \times 10^{-6}+7.8375 \times 10^{-7}+4.671 \times 10^{-2}=0.0467 \mathrm{~V}
$$


At the operating condition, water in the cell remains in its vapour state and the saturated pressure of the humidified air: $0.2564 \mathrm{~atm}$ and $0.4706 \mathrm{~atm}$ were estimated at the respective temperatures $65^{\circ} \mathrm{C}$ and $80^{\circ} \mathrm{C}$.

$$
P_{a t m .}(\mathrm{T})=-2846+411.24 \mathrm{~T}-10.554 \mathrm{~T}^{2}+0.16636 \mathrm{~T}^{3}
$$

The amount of oxygen in the humidified air available for the cell oxidation reactions was estimated from the concentration of the water and air using the Relative Humidity (RH) relationship. Given that dry air contains approximately 21\% Oxygen, 0.1562 fraction of Oxygen $\mathrm{CO}_{2, \mathrm{~S}, 65}$ was available for the oxidative reaction at the operating condition. That is, for 0.1112 fractions of Oxygen $\left(\mathrm{CO}_{2, \mathrm{~s}, 80}\right)$ in the humidified air at $80^{\circ} \mathrm{C}$; more oxygen is available for the cell operation at $65^{\circ} \mathrm{C}$.

$$
\mathrm{RH}=\frac{\mathrm{P}_{\mathrm{i}}}{\mathrm{P}_{\mathrm{sat}}(\mathrm{T})}=\frac{\mathrm{y}_{\mathrm{vap}} \mathrm{P}_{\mathrm{T}}}{\mathrm{P}_{\mathrm{sat}}(\mathrm{T})}
$$

Taking a unit electron transfer ( $\mathrm{z}=1$ ) and ORR order of 0.75 for negligible anodic transfer resistance at no change in exchange current density (i); $0.0073 \mathrm{~V}$ was lost due to availability of oxygen at the electrodes, giving gas constant (R): $8.314 \mathrm{~J} / \mathrm{mol} . \mathrm{K}$ for a 1 Faraday charge. That is,

$$
\begin{aligned}
& \eta_{o}=\eta_{o a}+\eta_{o c}=0+\eta_{o c}=\eta_{\mathrm{o}(65)}-\eta_{\mathrm{o}(80)}=\frac{R T}{(\mathrm{z}+\gamma) F} \ln \left(\frac{\mathrm{C}_{\mathrm{O}_{2}, \mathrm{~s}, 65}}{\mathrm{C}_{\mathrm{O}_{2}, \mathrm{~s}, 80}}\right) \\
& \text { And } \quad \eta_{o}=\frac{R}{(\mathrm{z}+\gamma) \mathrm{F}}\left[\mathrm{T}_{65} \ln \mathrm{C}_{\mathrm{O}_{2}, \mathrm{~s}, 65}-\mathrm{T}_{80} \ln \mathrm{C}_{\mathrm{O}_{2}, \mathrm{~s}, 80}\right]
\end{aligned}
$$

The concentration loss can be averted if EtOH transfer to the electrode surface is greater or equal to the rate of consumption. Empirically, at the anode, Larminier and Dicks (2003) have suggested polarization due to concentration as a simple model of a complex fuel cell. Taking $m=2 \times 10^{-5} \mathrm{~V}$ and $n=$ $7 \mathrm{~cm}^{2} / A$, at current density $1.1 \mathrm{~A} / \mathrm{cm}^{2}$, the cell is inherent of $0.0442 \mathrm{~V}$ loss due to transfer resistance.

$$
\eta_{m}=m e^{n i}=0.0442 \mathrm{~V}
$$

Therefore, $0.0515 \mathrm{~V}$ is lost due to concentration:

$$
\eta_{\text {Conc }}=\eta_{o}+\eta_{m}=0.0073+0.0442=0.0515 \mathrm{~V}
$$

Therefore, the simulated cell was inherent of $0.1211 \mathrm{~V}$ over-potential due to activation, conduction and concentration losses: $\mathrm{V}_{\mathrm{L}}=\eta_{a}+\eta_{\mathrm{r}}+\eta_{\text {Conc. }}=0.0229+0.0467+0.0515=0.1211 \mathrm{~V}$

Thermodynamically, 452.47kJ energy generation is estimated per mole of EtOH consumed in the cell. As indicated in the cell reactions, $9.84 \mathrm{~kJ} / \mathrm{g}$ specific energy can be generated by $1 \mathrm{M} \mathrm{EtOH}$ : 


$$
\Psi=\frac{-\Delta \mathrm{G}_{\text {cell }}^{\mathrm{o}}}{\mathrm{M}_{\mathrm{EtOH}}}=9.84 \mathrm{~kJ} / \mathrm{g}
$$

Applying the Nernst equation for the stoichiometric cell reaction (4e $\mathrm{e}^{-}$transfer); the minimum possible voltage that is, thermodynamic voltage, to drive the cell reaction without irreversibility is the cell emf estimated as:

$$
\mathrm{E}_{\mathrm{o}}=\frac{-\Delta \mathrm{G}_{\text {actual }}^{\mathrm{c}}}{\mathrm{nF}}=1.1724 \text { VoltsSHE }
$$

Giving the available cell potential as

$$
\mathrm{E}_{\text {cell }}=\mathrm{E}_{\mathrm{o}}-\mathrm{V}_{\mathrm{L}}=1.0513 \mathrm{~V}
$$

Recall, the cell operates at a constant temperature. However, increased thermal energy enhances the cell reaction. To maintain the operating temperature while trying to maintain and/or enhance the cell reaction, the cell voltage adjusts above the thermodynamic voltage. This adjusted voltage becomes the thermoneutral voltage $\left(E_{\text {th }}\right)$ if its product with current generated heat to drive the process while keeping the operating temperature constant. In view that the reaction energies went into useful work and the rate of entropy change being zero, the $\mathrm{E}_{\text {th }}$ is the maximum voltage for the reversible adiabatic process.

$$
\Delta \mathrm{H}_{298}=-1370 \mathrm{~kJ} / \mathrm{molEtOH}
$$

$$
\mathrm{E}_{\mathrm{th}}=\frac{-\Delta \mathrm{H}}{\mathrm{nF}}=3.549 \mathrm{~V}
$$

Based on the conservation of current ( $i_{\text {cell }}=i_{a}=i_{c}$ ), and for the current flow area of $50 \mathrm{~cm}^{2}$ and a current density of $0.6 \mathrm{~A} / \mathrm{cm}^{2}$ from the Ohmic region of the polarization curve (Fig 2); the cell is capable of a 30A. Evoking Watt's law: $106.50 \mathrm{~W}$ power was generated from the maximum voltage and the irreversible power $\left(\mathrm{P}_{\mathrm{L}}\right)$ of the cell $(3.633 \mathrm{~W})$ was estimated from the $0.1211 \mathrm{~V}$ lost voltages:

$$
\begin{aligned}
& P=\mathrm{IV}=\mathrm{I} \eta_{i=a, r, C} \\
& P_{L}=\mathrm{I}\left(\eta_{\text {act }}+\eta_{r}+\eta_{\text {conc }}\right)=0.6871+1.4011+1.5451=3.633 \mathrm{~W}
\end{aligned}
$$

In view of fuel dilution and low fraction of oxygen in the humidified air in operation, the emf of the cell cannot be considered as the ideal voltage of the cell hence cannot assess the ideal power of the cell (Gaggioli \& Dunbar, 1993). The specific electrical power is generated for a 90 -second operation $(\mathrm{kW} / \mathrm{g})$.

$$
\mathrm{p}_{\text {cell }}=\frac{-\Delta \mathrm{G}_{\text {cell }}^{\mathrm{N}}}{90 \mathrm{MW}}=0.1092 \mathrm{~kW} / \mathrm{g}
$$

Therefore, at $0.31 \mathrm{~g}$ EtOH feed, 90 seconds operation, 3.05kJ of energy is produced resulting in $33.89 \mathrm{~W}$ of ideal power generation and $1.1267 \mathrm{~V}$ ideal voltage. 


$$
P_{G}=0.31 * \mathrm{p}_{\text {cell }}=0.03389 \mathrm{~kW}
$$

\section{Efficiency}

Under reversible conditions, the possible thermodynamic efficiency gives the ratio of the actual electrical work to the potential electrical work. Thus, the ratios: minimum expected voltage: $\mathrm{E}_{\mathrm{o}}(1.1724 \mathrm{~V})$ to thermoneutral voltage: $\mathrm{E}_{\text {th }}$ (3.549V) gave a 33\% reversible efficiency $\left(\varepsilon_{\mathrm{r}}\right)$ and actual cell voltage $E_{\text {cell }}$ $(1.0513 \mathrm{~V})$ to the thermoneutral voltage give a $30 \%$ actual efficiency $\left(\varepsilon_{\mathrm{I}}\right)$

$$
\begin{aligned}
& \varepsilon_{r}=\frac{E_{o}}{E_{t h}}=\frac{\Delta \mathrm{G}^{\circ}}{\Delta \mathrm{H}}=\frac{1.1724}{3.549}=\frac{452.45}{1370}=0.33 \\
& \varepsilon_{\mathrm{I}}=\frac{E_{\text {cell }}}{E_{\text {th }}}=\frac{1.0513}{3.55}=0.30
\end{aligned}
$$

The proportion of the actual power output $\left(\mathrm{P}_{\text {act }}\right)$ with respect to the ideal power $\left(\mathrm{P}_{i}\right)$ indicates the FC Efficiency $\left(\varepsilon_{\text {cell }}\right)$. Therefore, 89\% efficiency is expected for a $1.0513 \mathrm{~V}$ cell of $1.1724 \mathrm{~V}$ emf.

$\varepsilon_{\text {cell }}=\frac{\mathrm{P}_{\text {act }}}{\mathrm{P}_{i}}=\frac{30.16}{33.89}=0.89$

Considering $0.5 \mathrm{~V}$ working ideal voltage and $0.1 \mathrm{~A} / \mathrm{cm}^{2}$, a conforming electrochemical efficiency of $43 \%$ was calculated.

$$
\varepsilon_{\text {elect }}=\frac{\mathrm{V}_{i}}{\mathrm{E}_{\mathrm{o}}}=\frac{0.5}{1.1724}=0.4265
$$

Ideally, the FC is expected to have $39 \%$ and $14 \%$ Potential efficiencies under reversible and ideal electrochemically operating conditions respectively:

$$
\begin{aligned}
& \varepsilon_{\text {P.rev }}=\varepsilon_{\text {cell }} * \varepsilon_{\text {elect }}=0.90 \times 0.43=0.38 .7 \\
& \varepsilon_{\text {P.ideal }}=\varepsilon_{\text {th }} * \varepsilon_{\text {elect }}=0.33 * 0.43=0.14
\end{aligned}
$$

\section{The DEFC Operation}

The 30W simulated DEFC operated with a $3.4 \mathrm{M}$ aqueous ethanol solution prepared from $95 \%$ ethanol and distilled water and fed to the anode via the cell flow channels. Through the DL, the EtOH solution diffused to the catalyst where the oxidation of EtOH and reduction of water took place. At $2 \mathrm{~cm}^{3} / \mathrm{s}$ EtOH dosed, considering $\mathrm{PtSn} / \mathrm{C}$ electrocatalyst at $65^{\circ} \mathrm{C}$, the redox reactions released charges $\left(\mathrm{H}^{+}\right.$and $\left.\mathrm{e}^{-}\right)$and produce $\mathrm{CH}_{3} \mathrm{CHO}$ which oxidized further to $\mathrm{CH}_{3} \mathrm{COOH}$ and $\mathrm{CO}_{2}$. The protons $\left(\mathrm{H}^{+}\right)$were transferred by potential difference via the PEM (Nafion ${ }^{\circledR} 127$ ) to the cathode and the electrons drawn from the anode, passing through the external circuit (Load) as direct electric current, to the cathode. At the cathode, oxygen from the humidified air promoted the cathodic charge transfer reactions thus producing water. Note: at the membrane, the electrodes, layers, and the electron transfer materials; as 
well as operating conditions, potentials were lost thus power generated was not the power available.

Table 1: Summary of exergy analysis of the direct 95\% ethanol fuel cell (DEFC)

\begin{tabular}{cc}
\hline Parameter & Value \\
\hline Thermodynamic Voltage $\left(\mathrm{E}_{\mathrm{o}}\right)$ & $1.1724 \mathrm{~V}$ \\
Cell Voltage $\left(\mathrm{E}_{\text {cell }}\right)$ & $1.0513 \mathrm{~V}$ \\
Cell Overpotential & $0.1211 \mathrm{~V}$ \\
Ideal Voltage of Cell & $1.1267 \mathrm{~V}$ \\
Electrical Energy & $3.050 \mathrm{~kJ}$ \\
Ideal Power & $33.79 \mathrm{~W}$ \\
Actual Power & $30.16 \mathrm{~W}$ \\
Irreversible Power & $3.633 \mathrm{~W}$ \\
Reversible efficiency & $33 \%$ \\
Irreversible efficiency & $30 \%$ \\
Cell efficiency & $89 \%$ \\
Gibbs Free Energy $\left(\Delta \mathrm{G}^{\circ}\right)$ & $-452.47 \mathrm{~kJ} / \mathrm{mol}$ \\
Enthalpy $\left(\Delta \mathrm{H}^{\circ}\right)$ & $-1370 \mathrm{~kJ} / \mathrm{mol}$ \\
\hline
\end{tabular}

\section{Discussions}

The low feed concentration of $20 \% \mathrm{EtOH}$ and the $2 \mathrm{~cm}^{3} / \mathrm{s}$ dosing rate that generated the $3.042 \mathrm{~kJ}$ energy was a pointer ascertaining the viability of ethanol in substantive power generation even at very low amounts.

Though high cell operating temperature will ensure quick and easy start of the cell reactions, the energy expended in the cell ignition enhances the losses due to activation. The nonspontaneous $65^{\circ} \mathrm{C}$ operating temperature resulted in the $0.0216 \mathrm{~V}$ considerable loss. At low operation temperature typical of low to negligible loss; a feasible and readily functional cell is very likely unattainable. From the model, increase in operating temperature brings about an increase in activation over potential; for every $10^{\circ}$ rise in operation temperature; the over potential increases by $0.0006 \mathrm{~V}$.

Following the advent of very suitable membrane and layer materials inherent of adequate ion, and electron mobility and transfer; $59 \mu \mathrm{m}$ thick wet Nafion ${ }^{\circledR}$ 112, $0.025 \mathrm{~cm}$ thick woven-carbon-cloth DL of $20 \%$ polytetraflouroethelyne (PTFE) was considered thus ensuing the $8.91 \times 10^{-6} \mathrm{~V}$ loss due to ionic and electronic conductivity. This loss is a very negligible proportion of the $0.0467 \mathrm{~V}$ Ohmic loss and it is typical of the loss due to componental contact. This points the need to ensure proper contact area, and conscious component fittings and tightening. The highest loss of $0.0515 \mathrm{~V}$ recorded was due to concentration: largely due to EtOH transfer resistance; signifying the fuel availability at site is very key. Componental contact enhanced charge transport, concentration and permeability improves fuel transport thus the losses and generation were chiefly due to transport. 
Therefore, the major losses in the simulated cell as indicated: $0.0467 \mathrm{~V}$ and $0.0515 \mathrm{~V}$ were due to charge and reactant transport. Transport dependent on material features and properties: permeability of membranes and layers, available contact surface area, and material specifications. These losses due to transport amounted to circa $80 \%$ of the $0.1211 \mathrm{~V}$ loss inherent in the simulated cell. The specification of thin material of high conductivity and permeability was inherent in ensuring portability and optimal operation of the cell in its application for power generation.

At a loss of $0.1211 \mathrm{~V}$ from the $1.1724 \mathrm{~V}$ OCV, the simulated cell was inherent of $1.0513 \mathrm{~V}$ potential hence probable of generating $31.539 \mathrm{~W}$ of power. Considering the OCV was estimated from stoichiometry, the $31.539 \mathrm{~W}$ generation was due to $4 \mathrm{e}^{-}$stoichiometric release. The cell operating at $2 \mathrm{~cm}^{3}$ $20 \% \mathrm{EtOH}$ feed per second released $0.0272 \mathrm{e}^{-}$from the 0.0068 moles fed.

Thermodynamically, EtOH has $452.47 \mathrm{~kJ} / \mathrm{mol}$ energy available for reversible power generation; therefore, the $9.84 \mathrm{~kJ} / \mathrm{g}$ energy density for $20 \%$ EtOH solution was an assenting certification to the propensity of EtOH as a viable power generation biofuel. At this energy density; for a $0.31 \mathrm{~g} \mathrm{EtOH}$ feed at $0.0068 \mathrm{~mol} / \mathrm{s}$ molar rate and $1.5 \mathrm{~min}$ operation time, the cell was able to generate $0.109 \mathrm{~kW} / \mathrm{g}$ power density, thus producing $3.050 \mathrm{~kJ}$ energy and $33.79 \mathrm{~W}$ useful reversible power. Therefore, at $0.1211 \mathrm{~V}$ overpotential, the simulated cell lost $3.633 \mathrm{~W}$ power and produced $30.16 \mathrm{~W}$ of useful irreversible power.

Higher temperatures have indicated an enhancement to the fuel cell reaction, thus the reaction is considered endothermic. That is, as the cell reaction proceeded, the electrodes get cold due to endothermicity. Therefore, the excess energy due to $E_{\text {th }}$ sustained the reaction and kept the operating temperature constant.

Since the cell capacity was based on the available power, the ratio of the thermodynamic voltage to the Thermoneutral voltage indicated that 33\% of the power generated in the cell was actually available for external use for negligible operational losses given the reversible efficiency. However, considering the inherent significant losses, the DEFC operated at a 30\% irreversible efficiency. The DEFC was capable of approximately 89\% available power as the useful power output.

Taking proper and cognizant material specification, adjusting operating temperature and considering suiting materials' parameters; DEFCs capable of generating any amount of power can be simulated from existing models.

\section{Conclusions}

The significant energy and power generation: $3.042 \mathrm{~kJ}$ and $30.16 \mathrm{~W}$ from the simulation with the low feed concentration: $20 \% \mathrm{EtOH}$ at $2 \mathrm{~cm}^{3} / \mathrm{s}$ 
dosing rate was a pointer ascertaining the viability of ethanol in fuel cells. Therefore, taking proper materials' specification and making cognizant adjustments in the operational parameters including temperature, it is evident that DEFCs capable of generating any given amount of power can be simulated from extant models.

\section{Recommendation}

Advancement in DEFCs will help the economy of ethanol producing nations as it would indicate a conscious and very eco-friendly shift in power and energy source. It will also prevent, leverage and control the worldwide menace that threatens human existence: the greenhouse effect.Seeing the current leap of the world aiming towards renewable and clean energy, material and parameter manipulations in the application of ethanol in fuel cell encourages and thus promises a speedy diversification in power generation and the remediation of environmental threat due to fossil fuel.

\section{References:}

1. Abdullah, S., Kamarudin, S., Hasran, U. M., \& Daud, W. (2014). Modeling and simulation of a direct ethanol fuel cell: An overview. Journal of Power Sources, 262, 401-406.

2. Abdulrazzak, A., \& Abdullah, N. (2021). Performance Analysis of Hybrid Solid Oxide Fuel Cell -Gas Turbine Power System. The International Journal of Engineering and Science (IJES), 9(9), 43-51.

3. Agboola, P. O., \& Agboola, M. O. (2011). Nigera's Bio-Ethanol: Need for Capacity Building Strategies to prevent Foo Crises. World Renewable Energy Congress (pp. 258-265). Linkoping, Sweden: Bioenergy Technology.

4. Ajayi, O. O., Rasheed, K., Abiodun, O., \& Toyese, O. (2020). Technoeconomic Assessment of Transforming Sorghum Bagasse into Bioethanol Fuel in Nigeria: 1-Process Modeling, Simulation, and Cost Estimation. Journal of Engineering Studies and Research, 154-164.

5. Andreadis, G., Podias, A., \& Tsiakaras, P. (2008). The effect of the parasitic current on the Direct Ethanol PEM Fuel Cell Operation. Journal of Power Sources, 214-227.

6. Back-Sub, S., \& Young-Hoon, Y. (2016). Direct Ethanol Fuel Cell (DEFC) Assembled with Ceramic Membrane-Catalyst. International Journal of Energy and Power Engineering., 5(6), 209-214.

7. Braide, W., Kanu, I., Oranusi, U., \& Adeleye, S. (2016). Production of bioethanol from agricultural waste. . Journal of Fundamental and Applied Sciences, 372.

8. Ehlinger, V. M., Andrew, R. C., Ahmet, K., \& Adam, Z. W. (2020). Modeling proton-exchange-membrane fuel cell 
performance/degradation tradeoffs with chemical scavengers. Journal of Physics and Energy.

9. Elleuch, A. K., Halouani, \& Li, Y. (2016). Bio-methanol fueled intermediate temperature solid oxide fuel cell: A future solution as component in auxiliary power unit for eco-transportation. Material of Desalination, 331-340.

10. Gaggioli, R. A., \& Dunbar, W. R. (1993). Emf, Maximum Power and Efficiency of Fuel Cell. Journal of Energy Resources Technology, 100-104.

11. Haghighi, M., \& Sharifhassan, F. (2016). Exergy analysis and optimization of a high temperature proton exchange membrane fuel cell using genetic algorithm. Exergy analysis and optimization of a high temperature proton exchange membrane fuel cell using geCase Studies in Thermal Engineering, 207-217.

12. Larminier, J., \& Dicks, A. (2003). Fuel Cell System Explained. West Sussex, England: John Wiley \& Sons Ltd.

13. Mench, M. M. (2008). Fuel Cell Engines. New Jersey: John Wiley \& Sons.

14. Mert, S., Toprak, M., \& Depci, T. (2019, September). Exergetic Simulation and Performance Analysis of the Effect of Flow Patterns in PEMFCs. International Journal of Thermodynamics (IJoT), 19(4), 159-166.

15. Modupe, E. O., Akwayo, I. J., Olugbenga, S. T., Oyinlola, M. O., Ayodeji, A. A., Ojawumi, E. O., \& Oyeniyi, E. A. (2018). BioConversion of Sweet Potato Peel Waste to Bio-Ethanol Using Saccharomyces Cerevisiae. International Journal of Pharmaceutical and Phytopharmacological Research, 8(3), 46-54.

16. Oyegoke, T., \& Dabai, F. (2018). Techno-economic feasibility study of bioethanol production from a combined cellulose and sugar feedstock in Nigeria: 1-modeling, simulation, and cost evaluation. Nigerian Journal of Technology, 913-920.

17. Oyegoke, T., Dabai, F., Muhammed, J. A., \& Jibril, B. E.-Y. (2017). Oyegoke, T., Dabai, F.Process Modelling and Economic Analysis for Cellulosic Bioethanol Production in Nigeria. 1 st National Conference on Chemical Technology. .

18. Renewable Fuels Association (RFA). (2021, August 15). Why is Ethanol Important. Retrieved from ethanolrfa.org: http://ethanol.org/ethanol-101/why-is-ethanol-important

19. Saisirirat, P., \& Joommanee. (2018). Study on the micro direct ethanol fuel cell (Micro-DEFC) performance. 8th TSME-International Conference on Mechanical Engineering (TSME-ICoME 2017) (pp. 135). Saisirirat, Penyarat; Joommanee, Bordindech 8th TSME- 
InternationalIOP Conference Series: Materials Science and Engineering 297.

20. Song, S., \& Tsiakaras, P. (2006). Recent progress in direct ethanol proton exchange membrane fuel cells (DE-PEMFCs). Applied Catalysis B: Environmental, 187-193.

21. Zakaria, Z., Kamarudin, S., \& Timmiati, S. (2016). Membranes for direct ethanol fuel cells: An overview. Applied Energy, 334-342. 